\title{
Multiliteracies of Transnational and Immigrant Pre-teens: Meditating Intercultural Meaning
}

Nettie Boivin

Graduate School of Education

\section{Abstract}

With the increase in cultural and economic globalization and technological advancements, the very nature of communication has become more fluid. As a result, communication practices move past defining socio-cultural identity to become intercultural capital from which a more constructive bicultural identity can emerge. This study compares immigrant and transnational migrant multiliteracies at the transitional age of pre-adolescence, comparing both global and socio-cultural types. The study utilised ethnographic collective case study observation of three Nepalese families in the United Kingdom. The year-long study comparatively investigated; what types of multiliteracies do immigrant and transnational pre-teens participate in? And do these multiliteracies better enable constructive identity through intercultural capital? The research utilised 150 hours of ethnographic observation, meta-historical narratives and semi-structured interviews with three case study families who were transnational Gorkha and immigrant Nepalese in the U.K. Moreover, the study newly categorized three types of multiliteracies relevant to both transnational and immigrant pre-teens: those that are transnational, global cultural and peripheral ritualised multiliteracies. Findings from this article revealed that while pre-adolescences transnationals participated in transnational cultural and globalized multiliteracies, immigrant pre-teens partook predominately in globalized multiliteracies.

$\begin{array}{ll}\text { Original language } & \text { English } \\ \text { Pages (from-to) } & 1-17 \\ \text { Number of pages } & 17 \\ \text { Journal } & \text { Journal of Intercultural Communication Research } \\ \text { State } & \text { E-pub ahead of print - Sep 1 2016 }\end{array}$

Boivin, N. (2016). Multiliteracies of Transnational and Immigrant Pre-teens: Meditating Intercultural Meaning. Journal of Intercultural Communication Research, 1-17. DOI: $\underline{10.1080 / 17475759.2016 .1226932}$ 